\title{
Cristina Florescu (ed.), Terminologia meteorologică românească a fenomenelor atmosferice (știinţific versus popular), Editura Universității „Alexandru Ioan Cuza”, Colecția Dicționarele Editurii Universităţii, Seria Lexikon, Iași, 2015, 712 p. (cu CD-Rom)
}

\author{
Daniela Butnaru* \\ “A. Philippide” Institute of Romanian Philology, Str. Th. Codrescu 2, 700481 Iași, Romania
}

The present work belongs to the study of specific scientific terms, being the result of linguistic research on the designation of atmospheric phenomena in Romanian (considering the popular terminology as well as the scientific one), which has represented the core subject matter of a project funded by CNCS (PN-II-ID-PCE-2011-3-0656) and coordinated by Cristina Florescu, principal investigator at the "Alexandru Philippide" Institute of Romanian Philology from Iași (IFRI). Six other IFRI researchers have been involved in this project (Laura Manea, Elena Tamba, Alina Pricop, Cristina Cărăbuş, FlorinTeodor Olariu, Mădălin Patrașcu), together with linguists from other research centers (Maria Iliescu, Rodica Zafiu, Nistor Bardu, Mariana Neț) and, for a better understanding of the scientific meteorological terms, a couple of experts in this field have joined the team (Liviu Apostol and Dan Chelaru). The volume consists of a first part (a series of linguistic studies) and a second part (the Dictionary of Atmospheric Phenomena itself). The studies included in the first part have been developed to a great extent on the basis of the data collected for the dictionary, and they disclose to the reader a diversity of characteristics of the popular and scientific Romanian terminology describing atmospheric phenomena.

The Introduction presents the object of study (out of the category of lexemes specific to the meteorological language, only the lexemes designating atmospheric phenomena have been taken into consideration), the literature review of meteorological phenomena research (in the field of Romanian and Romance linguistics), the relationship between scientific and popular terminology, the stages of research (initially the production of a dictionary, afterwards the elaboration of several studies based on the lexicographical material), the principles that have substantiated the selection of terms in the dictionary, the selection of atmospheric phenomena (combining the linguistic perspective with the meteorological one), the problems in identifying and determining the lexico-semantic fields of the terms designating the atmospheric phenomena in Romanian.

Noticing that, despite some targeted writing, there is no linguistic study that analyzes the lexical group of precipitations as a whole, Cristina Florescu sets herself to contribute to the correction of this deficiency. The origin and semantic evolution of the term precipitation are presented, together with the status of research in the Romance and Romanian relevant literature, and the analysis of the lexical subfields of precipitations. The most thoroughly attested one, both on the popular and on the scientific level, is the subfield of rain (the intensity and duration, shape of raindrops, structural aspect and effects of this type of precipitation being terminologically marked by distinct lexemes). The semantic-lexical subfield of snowfall also proves to be very rich and expressive. A natural continuation of this study on Precipitations (p. 71-105) is the contribution signed by Elena Tamba, which analyses Deposits (p. 107127), "a relatively techy issue in the meteorological terminology" because, unlike common speakers, the majority of meteorologists consider that deposits don't belong to the sphere of meteorological phenomena (p. 107). The analysis of this category represents a challenge for the author of the study, being the first linguistic analysis of this lexical category in Romanian that includes over 130 terms. Many words denominating deposits or directly related phenomena certify the lexical creativity of common people, with very few of these words belonging strictly to the

\footnotetext{
*Email address:d_butnaru@yahoo.com.
} 
scientific register.

In order to excerpt the meteorological terms belonging to the popular terminology, Romanian linguistic atlases, glossaries, dialectal dictionaries and archives have also been used. The study Dialectal Aspects, signed by Florin-Teodor Olariu, presents a linguistic analysis of the dialectal element collected for this project, along with the phonetic issues discovered and the solutions proposed by the dialectologist, emphasizing the lexical diversity and semantic richness of the dialectal material corresponding to atmospheric phenomena in Romanian.

Based on 60 weather forecasts published in the Romanian media from the end of the $19^{\text {th }}$ century until the beginning of the $20^{\text {th }}$ century, Rodica Zafiu observes the formation and evolution of the meteorological discourse (From the History of the Meteorological Discourse: "Weather Forecast" in the Romanian Media Between 1884 and 1916, p. 241-258). The prediction part appears later in this kind of texts, at first just as plain, sometimes extremely schematic reports on the weather conditions from the publication date of the newspaper and the days before. Beside the use of some terms from the popular lexical fund, the influence of French (through calques and borrowings) in the process of creation of this type of terminology is important and obvious (especially if one compares the versions in Romanian and French of the reports sent by the Institute of Meteorology to newspapers at the end of the $19^{\text {th }}$ century.) The study also comprises a complex analysis of the lexicalsemantic, stylistic and syntactic features characterizing the terminology from the meteorological discourse of the time.

Very interesting is also the study signed by Nistor Bardu, Denotation and Connotation in the Meteorological Terms in Aromanian (p. 259-272), where the author describes from a semantic and stylistic point of view the most important names of the atmospheric phenomena in Aromanian, gathered both through fieldwork and different works and dictionaries. Among the selected terms, bumbunead, $\breve{a}$, bumbuned, bumbunidare and bumbunidat, $-\breve{a}$, of onomatopeic origin, excel in expressiveness. As a result of this research, we can infer that the terminology of atmospheric phenomena is in Aromanian, for the most part, similar to the one in Daco-Romanian, the author finding equivalents in Istro-Romanian and Megleno-Romanian; this is an argument, once again, for "the extraordinary unity of Romanian from a dialectal perspective" (p. 271).

The text of Maria Iliescu-Une caractéristique du roumain dans le champ lexical de la température (p. 273-280) - belongs to the totality of attempts to define the individuality of Romanian among the Romance languages, starting with the fact that Romanian is the only one that has not preserved the lat. tepidus. Using different examples, with fr. tiède ( $<$ lat. tepidus) translated with the help of several native Romanian speakers, the researcher analyses the equivalents of the term in Romanian. Depending on the context and on its positive or negative perception, tiède has been translated as cald "warm" or călduț "lukewarm, tepid" (considered most of the time perfect synonyms in the thermic domain), but also as călìu, călduros "warmish", plăcut "nice", blând "mild”, agreabil "agreeable" etc., and even răcoros "cool" (p. 274-279). Based on her analysis, the author concludes that we didn't preserve lat. tepidus due to the lack of precision of the term.

The study of Mariana Neț-Synchronic and Diachronic Variants in the Romanian Gastronomic Vocabulary. Verbal Groups Formed with the Nouns "Rain" and "Snow" (p. 281-292)-monitors the inclusion of the two terms (rain and snow) in different expressions used in writing out culinary recipes resulting from analogies with meteorological phenomena. Most of the cases, the author notices, are translations or calques of common phrases met in the Italian or French cooking books of the $19^{\text {th }}-20^{\text {th }}$ centuries. Some of them have resisted in the gastronomic lexis until now ([a turnala da drumul/a lăsa să cadă $]$ in ploaie - rainlike pouring, albă ca zăpada - snow white), others (a bate albusurile ca în zăpadă - snowlike egg whites whipping, or a bate omăt or a le face omăt) are not used any longer, being replaced by the expression a bate spuma - to beat to a foam.

In the first part of the present volume Cristina Cărăbuș carries out a comparative research of the scientific vs. popular terminology designating $\mathrm{Lu}$ minous, Audible, Electrical and Electrical-luminous Phenomena (p. 129-143), Laura Manea authors a rich study about the scientific and popular terms for Radiations (p. 145-181), and Liviu Apostol pieces together an interesting presentation about the institutional beginnings and evolution of meteorology (Considerations on the Development of Meteorology in Romania, p. 229-240). 
A great part of this volume is dedicated to the Dictionary of Atmospheric Phenomena (DFA, p. 325678 ), preceded by a very clear presentation of the editing norms, followed by 23 pages of Bibliography. As also shown in the title of the present work, the dictionary is intended, as much as possible, to differentiate between the scientific and the popular language levels and, consequently, for most entries it is pointed out by means of the symbols $\Xi$ and $\Theta$ to which terminology-scientific ( Ts) or popular (Tp) - they belong, "according to the diachronic circulation of the senses, subsenses, syntagms" (p. 315).

The lexicographic experience of the authors is reflected in the structure of the dictionary entries, showing the accent in the headword, then the grammatical category, the affiliation to the popular or to the scientific register, the circulation, definition, quotations, grammatical and lexicological assignments, the etymology and, for a maximum of accuracy, the author. The consistent or less consistent combinations "are processed under the headword that is their lexical center, under every meaning" (p. 314). The selection of the quotations gives the possibility to trace the evolution of terms and their meanings in time, thus revealing different periods in the development of the Romanian language. The authors' commitment to accuracy is so great that, when the definition is retrieved from another dictionary, this is indicated in brackets, plus other dictionaries (up to a maximum of ten) where the processed word is present.

One can notice the influence of the project DÉRom, to which four of the authors of the present work have contributed; thus the DFA uses, in the paragraph explaining the etymology of a headword, the indication "Protorom." - "innovative element pointing to the elements inherited from ProtoRomance (oral Latin indicating a conventionally fixed time frame in the evolution of Latin), according to the DÉRom project" (p. 319). We also emphasize that in the footnotes marked with an asterisk, the etymology of the phrases belonging to the scientific register is indicated, for instance: "Trombă de nisip - cf. fr. trombe de sable, engl. sand pillar (VILLENEUVE, p. 388). Trombă marină - cf. fr. trombe marine, eng[1]. waterspout (id. ib.)" (p. 620).

Phrases like crîngul cerului "celestial vault" (p. 401); fluture de zăpadă "snow butterfly" and măgură (sau mal) de zăpadă "hummock / bank of snow" (p. 671), spic de ploaie "ear of rain" or spic de zäpadă "ear of snow" (p. 596), struț de gheață "ice ostrich" (p. 600), troian de zäpadă "snowdrift" (p. 619) etc. certify the lexical creativity of the common speaker. Equally expressive seem to be the terms a coase "to sew", meaning "to freeze" (p. 395); cumpănă "cataract (with hail); cloud burst" (p. 403), a desfereca "to thaw" (p. 414), păliş "snowy or rainy wind, striking sidelong/sideways" (p. 537), a pişcura "to drizzle" (p. 546), sărăcilă [poverty bringer] "very dry and warm wind, blowing in Dobrogea, during the summer, destroying the crops" (p. 583), also named pietros "stoney" (p. 545), etc.

In the fortunate eventuality of a second edition of the book, the authors could review some aspects regarding the editing and conformity of information: adding to the bibliographical list on page 29 the work abbreviated as Zafiu 2003 (to which there is a reference on p. 16); the quotation from CIŞMAN on section Tp of the entry TROMB $\mathbf{A}$ (p. 620) should be placed, in our opinion, among the ones for Ts; we also believe that it would be better if, in the case of the phrase zăpada mieilor (p. 671) or omătul mieilor "lamb snow", al cocostîrcilor "stork snow", al oilor "sheep snow" or al păsărilor "bird snow" (p. 531), defined through "măzăriche / vetch, sleet", the main defining feature was the temporal one, that is snow falling in spring, during the time lambs are born or when migrating birds begin to return, which would justify the combination of these lexemes; the footnote on p. 525, which indicates the etymologies of several scientific expressions containing the word nor "cloud", for rupere de nori we are being referred to "engl. cloudburst", but also to "fr. averse torentielle", which should be eliminated. The etymology of the word troian, taken over from DLR ("from the toponym Troian"), is debatable (cf. Mircea Homorodean, About the Troian Toponym, in "Onomastic Studies", vol. III, edited by Ioan Pătruț, Eugen Pavel, Augustin Pop, Ion Roșianu and Gabriel Vasiliu, Cluj-Napoca, 1982, p. 97-105; also see the abstract of the communication Un toponim controversat: Valul lui Traian [A Controversial Toponym: Wave of Traian], presented in 2001 by Mircea Ciubotaru [online], p. 7).

We must emphasize the pioneering character of this work in the domain of meteorological terminology, granted by the complex linguistic analysis of the lexical field designating atmospheric phenomena 
in Romanian, by the comparative presentation of popular and scientific terms and their meanings, by the compilation and the inclusion in the dictionary of new material, of lexemes excerpted from dialectal works not included so far in other Romanian dictionaries. The impressive tome that we have hereby presented is also an important source of bibliography in the field of both general and meteorological ter- minology, considering that both the studies from the first part of the volume, and the dictionary from the second part are accompanied by numerous references to the relevant literature. The general interest in this domain explains the richness of its terminology and it is the reason why not only experts in linguistics or meteorology, but anybody can open and read the present work with great satisfaction. 